\title{
Independence, discipline and employability: Study of vocational high school students
}

\author{
Fatwa Tentama $^{1}$, Subardjo $^{2}$, Surahma Asti Mulasari ${ }^{3}$ \\ ${ }^{1}$ Faculty of Psychology, Ahmad Dahlan University, Indonesia \\ ${ }^{2}$ Faculty of Law, Ahmad Dahlan University, Indonesia \\ ${ }^{3}$ Faculty of Public Health, Ahmad Dahlan University, Indonesia
}

\begin{tabular}{l} 
Article Info \\
\hline Article history: \\
Received Mar 2, 2019 \\
Revised Apr 13, 2019 \\
Accepted Apr 24, 2019 \\
\hline
\end{tabular}

Keywords:

Discipline

Employability

Independence

Vocational high school

\begin{abstract}
Many factors can affect employability in Vocational High School students, including independence and disciplinary factors. This study aims to determine the role of independence and discipline towards student employability. As many as 225 students of class XII Vocational High School 1 Kalasan Yogyakarta, Indonesia participated in this study. The sampling technique is cluster random sampling. The research method used is a quantitative method with employability scale, independence scale, and discipline scale as a data collection tool. The data analysis used in this study is multiple linear regression analysis techniques. The findings show that there is a very significant effect between independence and discipline on employability. Partially, there is a very significant influence between independence towards student employability, and there is a very significant influence between discipline on employability. The role of discipline towards employability is more dominant than independence to employability in Vocational High School students.
\end{abstract}

Copyright $\odot 2019$ Institute of Advanced Engineering and Science. All rights reserved.

\section{Corresponding Author:}

Fatwa Tentama,

Faculty of Psychology,

Ahmad Dahlan University,

Kapas Street No.9, Semaki, Umbulharjo, Yogyakarta, Indonesia.

Email: fatwa.tentama@psy.uad.ac.id

\section{INTRODUCTION}

Vocational high school is an educational institution that prepares or produces human resources ready to work. At this level students are prepared to have skills, so that graduates will be ready to enter the workforce. The aim of vocational high school is to prepare students to be productive human beings, able to work independently, be able to choose careers, and be able to fill existing job vacancies as workers who have good employability. Based on the aim of the vocational high school, technically, vocational graduates have the employability to work because they have been equipped with skills that lead to work readiness independently, so that vocational high school can be a solution to reduce unemployment. But the reality in the field shows that vocational graduates are one of the biggest contributors to open unemployment in Indonesia.

Employability skills are essential for every individual in educational institutions, companies, and organizations. Educational institutions must prepare their students to have employability as a provision to get a job in the future [1]. This is in line with the opinion of Jameson [2] who emphasizes the importance of developing and improving student employability. Some experts believe that the availability of employability can help individuals to manage their careers better [3-4]. Employability can improve teamwork skills, communication, self-management analysis, and critical thinking [5]. 
The low level of employability has an impact on low self-esteem, effort, and willingness to enter the workforce [6]. Individuals with low employability tend to be more challenging to enter the workforce or get a job by the expected career [7]. Also, the current number of unemployed people is also caused by the low employability of individuals [8]. Another impact caused by low employability is inappropriate decision making, conflict, inappropriate leadership, low meta-cognitive skills, less effective performance, low social responsibility, and pessimism [9]. Therefore, employability is an ability, understanding, and personality needed to get a job [10].

Employability is a form of skill of special abilities that allows individuals to identify and be aware of career opportunities [11]. Employability is in the form of skills, knowledge, and competencies that enhance the ability of individuals to get jobs and more easily enter the labor market at various periods of the life cycle [12]. Rothwell and Arnold [13] add that employability is the ability of individuals to find work according to their interests or desires. These things show the importance of the role of employability that a person must have for provision to get a job and maintain it when it is working. Many factors that affect one's employability include independence and discipline. Independence is identified as the quality most often sought by employers in prospective employees because independence will be the primary quality that can affect employability [14]. Independence is one of the factors that help individuals to enter the labor market [15]. Individuals with independence are seen as having better employability in terms of attitudes, motivation, skills, and knowledge [16]. Additionally, some entrepreneurs consider that individuals with independence tend to have more employability and can adapt to new environments to get jobs [17].

Independence is defined as the belief that individuals must be independent of the dependence of others, especially regarding their ability to work [18]. According to Reynolds, Kamphaus, and Vannest [19] independence is defined as individual beliefs in their ability to solve problems and respond to stress effectively. Meanwhile according to Kim and Isma'il [20] independence is the ability of individuals to think and act without help or the influence of others and the ability to decide what should be done. Hornby [21] defines independence as the ability of individuals to face life's challenges and show creativity with instincts to benefit themselves and others or their environment. Furthermore, efforts to improve employability are applying disciplinary knowledge in the workplace environment, so that expectations of individual performance can be adequate by the regulations set in the organization [22]. Several studies have shown that improving non-academic skills such as listening, working effectively in teams, maintaining work discipline can develop effective employability so that it can help individuals increase opportunities for employment [23]. In line with the opinion of Raftopoulos, Coetzee, and Visser [24] which emphasizes the attribute that individuals must have related to employability is self-discipline. Rigorous disciplinary learning can improve educational outcomes, work skills, teamwork, and employability [23].

Discipline is defined as socially and morally responsible behavior motivated by intrinsic factors, not solely by anticipating external rewards or fear of punishment [25]. According to Low (26) discipline is the ability of an individual to act or take action regardless of the judgment or responsibility of others. Meanwhile, according to Duckworth [27] self-discipline is defined as the capacity to do what individuals want to do by managing their emotions and thoughts and knowing how to plan individual behavior to achieve their goals. Discipline is the capacity of individuals to actively work towards long-term goals and to resist temptation [28]. The purpose of this study was to determine the effect of independence and discipline on employability in Vocational High School students.

\section{RESEARCH METHOD}

\subsection{Research subject}

The subjects in this study are 225 students in State Vocational High School 1 Kalasan, Sleman, Yogyakarta with the class of XII. The selection of research subjects was randomized, with cluster random sampling technique.

\subsection{Measuring instrument}

In this study, the scaling model used for the scale of employability, independence, and discipline is the Likert scale. Employability is measured with the employability scale, referring to aspects of employability according to Dacre Pool and Sewell [22], namely: skills, knowledge, understanding, and personality attribution. Independence is revealed by the scale of independence style which refers to aspects of independence according to Steinberg [29], namely emotional autonomy, behavioral autonomy, and value autonomy. Discipline is revealed by using a disciplinary scale that refers to disciplinary aspects according to Harahap [30] namely understanding of rules, compliance, and obedience to rules, timeliness in implementation and completion of work and regularity of processes in carrying out tasks. 


\subsection{Validity and reliability of the measuring instrument}

The employability scale, which was tested on 61 participants, obtains a reliability coefficient score of .821 . The corrected item-total correlation index moves from .289 to .510 . The valid and reliable items that are used for research are 20 items.

The Independence Test with 61 test subjects, reveals a reliability coefficient score of .869 . The corrected item-total correlation index moves from .382 to .668. The valid and reliable items that are used for research are 15 items.

The disciplinary scale with 61 test subjects, the results of the reliability coefficient were .913 . The corrected item-total correlation index moves from .267 to .731 . The valid and reliable items that are used for research are 28 items.

\subsection{Data analysis}

The method for data analysis used parametric statistical methods. Data analysis was performed using SPSS 19.0 for windows, through multiple regression testing techniques, namely a statistical analysis technique to determine the effect of independence and discipline on employability. Before the multiple linear regression test, it is necessary to test the assumptions which consist of normality test, linearity test and multicollinearity test.

\section{RESULTS AND ANALYSIS}

\subsection{Normality test}

Table 1 shows the normality test results. The findings show that employability, independence, and discipline, produce a significance value of $.347, .055$, and .235 respectively. Each has $p>.05$, indicating that all the data is normally distributed. In other words, there is no difference between the level of distribution of sample scores based on population scores. Thus, the sample used can represent the population.

Table 1. Normality test

\begin{tabular}{lccc}
\hline Variable & Score K-SZ & Sig. & Remark \\
\hline Employability & .934 & .347 & Normal \\
Independence & 1.339 & .055 & Normal \\
Discipline & 1.034 & .235 & Normal \\
\hline
\end{tabular}

\subsection{Linearity test}

The linearity findings reveal that independence and employability has an F score of 120.775 and a significance level (p) of .000 , indicating that the relationship is linear. In other words, there is a line that connects independence to employability. Meanwhile, linearity test between discipline and employability results in F linearity of 209.981 with a significance level (p) of .000 . This indicates that the relationship is linear, or there is a straight line that connects discipline to employability.

Table 2. Linearity test

\begin{tabular}{lcccc}
\hline Variable & $\mathrm{F}$ & Sig. & Criteria & Remark \\
\hline Independence towards Employability & 120.775 & .000 & $\mathrm{P}<.05$ & Linear \\
Discipline towards Employability & 209.981 & .000 & $\mathrm{P}<.05$ & Linear \\
\hline
\end{tabular}

\subsection{Multicollinearity test}

The multicollinearity test was conducted to ensure there was no multicollinearity relationship between the two independent variables. The rule used to determine whether or not there is multicollinearity relationship is to see tolerance values $>.10$ and VIF $<10$. Based on the results of the analysis, it shows that independence and discipline have $\mathrm{VIF}=1.592(\mathrm{VIF}<10)$ and tolerance $.628=($ tolerance $>.10)$, then, neither independence nor discipline has no multicollinearity relationship.

Table 3. Multicollinearity test

\begin{tabular}{lccc}
\hline Variable & Tolerance & VIF & Remark \\
\hline Independence & .628 & 1.592 & No multicollinearity \\
Discipline & .628 & 1.592 & No multicollinearity \\
\hline
\end{tabular}




\subsection{Multiple linear regression test}

The regression test on the effect of independence on employability is $(t)=4.090$ with a significance level of $=.000(\mathrm{p}<.01)$, meaning that there is a very significant effect of independence on employability among students at Vocational High School 1 Kalasan. Meanwhile, the regression analysis of discipline towards employability obtained a value $(\mathrm{t})$ of $=9.613$ with a significance level of $=.000(\mathrm{p}<.01)$, indicating that there is a very significant influence on discipline towards employability students in State Vocational High School 1 Kalasan.

Table 4. The result of relationship analysis between variables

\begin{tabular}{lcccc}
\hline Variable & $\mathrm{t}$ & $\mathrm{Sig}$ & Criteria & Remark \\
\hline Independence towards Employability & 4.090 & .000 & $\mathrm{P}<.01$ & There is a very significant influence \\
Discipline towards Employability & 9.613 & .000 & $\mathrm{P}<.01$ & There is a very significant influence \\
\hline
\end{tabular}

The $\mathrm{F}$ test obtains a score of 125.032 with a significance level of $(\mathrm{p})=.000(<.01)$, meaning that independence and discipline simultaneously affect employability students in State Vocational High School 1 Kalasan. The size of the role of independence and discipline towards employability is indicated by the Adjusted R Square value $=.525$. In other words, independence and discipline contribute $52.5 \%$ towards employability. Meanwhile, the remaining $47.5 \%$ is influenced by other factors outside the variables studied.

Table 5. The result of double regression test

\begin{tabular}{lccll}
\hline Variable & Adjusted R Square & $\mathrm{F}$ & Sig & \multicolumn{1}{c}{ Remark } \\
\hline Independence and discipline towards Employability & .525 & 125.032 & .000 & $\begin{array}{l}\text { There is a very significant } \\
\text { influence }\end{array}$ \\
\hline
\end{tabular}

The results of the regression analysis of independence and discipline on student employability showed that independence and discipline simultaneously influenced student employability. Based on these results indicate that the first hypothesis is accepted so that the variable employability can be predicted based on independence and discipline. The two independent variables simultaneously contributed $52.5 \%$ to employability so that other variables could influence the remaining $47.5 \%$. Other factors that affect employability include employability activities [31], self-efficacy and cultural employability [32], proactive personality, boundaryless mindset, identity relevance, social networks, social support, self-esteem, job search and re-employment [4], positive emotions and commitments [33], involvement and community life [34], welfare and health [35]. Partially, the results of this study indicate that independence contributes to employability by $13.8 \%$ and the contribution of discipline to employability is $39.2 \%$. The influence of discipline on employability is more dominant than the independence of employability in students in State Vocational High School 1 Kalasan, Sleman.

In the second hypothesis proposed, it was found that independence influences the employability of students, indicating that the hypothesis is accepted. The findings are in line with previous studies that highlight independence as one of the influential factors that can predict individual employability [36]. Further studies also found that one of the efforts to improve individual employability is by exercising its independence. Additionally, exercising independence can shape the character of manners, tolerance, and selfcontrol [37]. Independence is considered as the most likely attribute to be desired by entrepreneurs because independence can build an ethos of hard work and individual teamwork which will later affect employability levels [14]. The independence of students in Vocational High Schools is shown by students having the ability to make their own decisions when faced with certain situations both at school and outside of school and dare to carry out those decisions with various consequences that are ready to be faced. Moreover, students are able and ready to adjust to changes in individual relationships with parents, students do not depend entirely on parents and have a set of principles about what is right and what is wrong, about which are essential, and which are not important both in the school, environment and the work environment in the future. Thus, independent students will get skills, knowledge, understanding, and form a good personality as capital to get a job and to be able to carry out their jobs.

In the third hypothesis proposed, it was found that there was an influence of disciplinary variables on the employability of students so that the hypothesis was accepted. The findings are supported by the theory that assumes that discipline is one of the attributes that individuals must have before seeking jobs. This is because work discipline can improve team building skills, job search and employability, and vocational skills, making it easier for individuals to map career plans following interest, ability, and work 
motivation [38]. One of the factors causing low employability is because individuals lack work discipline and commitment to work [39]. To develop effective employability, it requires learning with discipline in the actual context, individuals who have discipline tend to have more opportunities to find a job [23]. The manifestation of student discipline is an understanding of the applicable regulations, compliance, and obedience to rules, the timeliness in the implementation and completion of tasks and the regularity of the process in carrying out their duties. Therefore, the existence of these disciplinary behaviors will ensure students to be more ready to work because it will indirectly increase the knowledge and skills acquired in school, understand the tasks quickly and form a good personality in students.

The difference and renewal of this research with previous research that in the psychology field of research education on employability issues is still rarely done. Employability problems in the field of education, especially vocational education are rarely done because vocational students are seen as having the knowledge and work skills that have been obtained at school. But the reality in the field shows the opposite, that vocational graduates make the biggest contribution to unemployment in Indonesia. In the field of psychology education, independence and discipline factors are the dominant factors affecting the employability of vocational students and vocational graduates.

The implications of this study can provide insight and awareness to students, parents, and teachers. This research shows that students' independence and discipline have a role in preparing students to get jobs and complete their work after graduating from Vocational High Schools, so these variables must be considered in everyday life. Parents and teachers must be able to create a positive environment that can provide opportunities for students to grow and develop their independence and discipline. The results of this study can also be used as a reference to compile training modules to deal with problems in Vocational High School students, especially in training to improve vocational students' work readiness through training in independence and discipline.

\section{CONCLUSION}

The conclusions of this study include: 1) Simultaneously, there is a very significant effect of independence and discipline on the employability of students in State Vocational High School 1 Kalasan. 2) There is a very significant effect of independence on the employability of students in State Vocational High School 1 Kalasan. 3) There is a very significant influence on the discipline of employability of students in State Vocational High School 1 Kalasan. 4) The role of discipline towards employability is more dominant than the independence of employability in students at Vocational High School 1 Kalasan.

\section{ACKNOWLEDGEMENTS}

The author would like to thank the Institute of Research and Community Service (LPPM) of Universitas Ahmad Dahlan in Yogyakarta for providing research funds so that this research could be carried out and resolved smoothly. The author also wants to thank State Vocational High School 1 Kalasan, Sleman, Yogyakarta, which has supported and participated in the research process.

\section{REFERENCES}

[1] Wang, Y. F., and Tsai, C. T. "Employability of hospitality graduates: Student and industry perspectives," Journal of Hospitality \& Tourism Education, vol. 26, no. 3, pp. 125-135, 2014.

[2] Jameson, S. M., "A case study of international hospitality students development of employability skills," Tourism and Hospitality Research, pp. 57-59, 2008.

[3] Hess, N., Jepsen, D. M., and Dries, N., "Career and employer change in the age of the "boundaryless' career," Journal of Vocational Behavior, vol. 81, no. 2, pp. 280-288, 2012.

[4] McArdle, S., Waters, L., Briscoe, J. P., and Hall, D. T. "Employability during unemployment: Adaptability, career identity and human and social capital," Journal of Vocational Behavior, vol. 71, no. 2, pp. 247-264, 2007.

[5] Lowden, K., Hall, S., Elliot, D., and Lewin, J., Employers' perceptions of the employability skills of new graduates, London: Edge Foundation, 2011.

[6] Benabou, R., and Tirole, J., "Self-confidence and personal motivation," The Quarterly Journal of Economics, vol. 117, no. 3, pp. 871-915, 2002.

[7] Yorke, M., and Knight, P., "Evidence-informed pedagogy and the enhancement of student employability," Teaching in Higher Education, vol. 12, no. 2, pp. 157-170, 2007.

[8] Ronnås, P., and Shamchiyeva, L., Employment diagnostic analysis: Maluku, Indonesia, Geneva: International Labour Organization, 2011.

[9] Jackson, D., and Chapman, E., "Non-technical skill gaps in Australian business graduates," Education Training, vol. 54, no. 2/3, pp. 95-113, 2012.

[10] Yorke, M., Employability in higher education: What it is - what it is not, York: Higher Education Academy, 2004. 
[11] Fugate, M., and Kinicki, A. J., "A dispositional approach to employability: Development of a measure and test of implications for employee reactions to organizational change," Journal of Occupational and Organizational Psychology, vol. 81, no. 3, pp. 503-527, 2008.

[12] Brewer, L., Enhancing youth employability: What? Why? and How? Guide to core workskills. Geneva: International Labour Organization, 2013.

[13] Rothwell, A., and Arnold, J., "Self-perceived employability: Development and validation of a scale," Personnel Review, vol. 36, no. 1, pp. 23-41, 2005.

[14] Nash, R., Stansbie, P., and Bruce, F., "An exploratory investigation into the effects backpacker travel can have on graduates'future employability," International Journal of Arts \& Sciences, vol. 4, no. 25, pp. 91-100, 2011.

[15] Giddens, A. Sociology. Cambridge: Polity Press, 2003.

[16] McNeill, J. "Employability pathways and perceptions of 'work' amongst single homeless and vulnerably housed people," Social Policy and Society, vol. 10, no. 4, pp. 571-580, 2011.

[17] Lees, D. Graduate employability-literature review, York: LTSN Generic Centre, 2002.

[18] Edwards, J. C., Rust, K. G., McKinley, W., and Moon, G. "Business ideologies and perceived breach of contract during downsizing: The role of the ideology of employee self-reliance," Journal of Organizational Behavior: The International Journal of Industrial, Occupational and Organizational Psychology and Behavior, vol. 24, no. 1, pp. 1-23, 2003.

[19] Reynolds, C. R., Kamphaus, R. W., and Vannest, K. J., Behavior assessment system for children, New York, NY: Springer, 2011.

[20] Kim, I., and Isma'il, M., "Self-reliance: Key to sustainable rural development in Nigeria," ARPN Journal of Science and Technology, vol. 3, no. 6, pp. 585-591, 2013.

[21] Hornby, A. S., Oxford advanced learner's dictionary. Oxford: Oxford University Press, 2017.

[22] Dacre Pool, L., and Sewell, P., "The key to employability: Developing a practical model of graduate employability," Journal of Education and Training, vol. 49, no. 4, pp. 277-289, 2007.

[23] Lerman, R. I., "Are employability skills learned in US youth education and training programs?," IZA Journal of Labor Policy, vol. 2, no. 1, pp. 1-20, 2013.

[24] Raftopoulos, M., Coetzee, S., and Visser, D., "Work-readiness skills in the Fasset Sector. SA," Journal of Human Resource Management, vol. 7, no. 1, pp. 119-126, 2009.

[25] Bear, G. G. From school discipline to self-discipline, New York: Guilford Press, 2010

[26] Low, K. "Leadership lessons from confucius, the 9Ps and confucian pillars of self-discipline," Business Journal for Entrepreneurs, pp. 1-15, 2012.

[27] Duckworth, A. L. Grit: The power of passion and perseverance. New York, US: Scribner/Simon \& Schuster, 2016.

[28] Hagger, M. S., Zhang, C. Q., Kangro, E. M., Ries, F., Wang, J. C., Heritage, B., and Chan, D. K. "Trait self-control and self-discipline: Structure, validity, and invariance across national groups," Current Psychology, pp. 1-16, 2018.

[29] Steinberg, L. Adolescence, Boston: Mcgraw-Hill, 2002.

[30] Harahap, A. K. " Application of additional employee income in improving employee performance and discipline in the regional staffing agency of North Sumatra Province," Master's Thesis. Universitas Sumatera Utara. Medan, 2011.

[31] Van Dam, K., "Antecedents and consequences of employability orientation," European Journal of Work and Organizational Psychology, vol. 13, no. 1, pp. 29-51, 2004.

[32] Nauta, A., Van Vianen, A., Van der Heijden, B., Van Dam, K., and Willemsen, M., "Understanding the factors that promote employability orientation: The impact of employability culture, career satisfaction, and role breadth selfefficacy," Journal of Occupational and Organizational Psychology, vol. 82, no. 2, pp. 233-251, 2009.

[33] Fugate, M., \& Kinicki, A. J. "A dispositional approach to employability: Development of a measure and test of implications for employee reactions to organizational change," Journal of Occupational and Organizational Psychology, vol. 81, no. 3, pp. 503-527, 2008.

[34] De Cuyper, N., Bernhard-Oettel, C., Bernston, E., De Witte, H., and Alarco, B., "Employability and employees' well-being: Mediation by job insecurity," Applied Psychology, vol. 57, no. 3, pp. 488-509, 2008.

[35] Berntson, E., and Marklund, S., "The relationship between perceived employability and subsequent health," Work \& Stress, vol. 21, no. 3, pp. 279-292, 2017.

[36] Jang, Y., Wang, Y. H., and Wang, J. D. "Return to work after spinal cord injury in Taiwan: the contribution of functional independence," Archives of Physical Medicine and Rehabilitation, vol. 86, no. 4, pp. 681-686, 2005

[37] Ee, J., \& Soh, K. "Teacher perceptions on what a functional curriculum should be for children with special needs," The International Journal of Special Education, vol. 20, no. 2, pp. 6-18, 2005.

[38] Ngai, S. Y., and Ngai, N. P., "Empowerment or disempowerment? A review of youth training schemes for nonengaged young people in Hong Kong," Adolescence, vol. 42, no. 165, pp. 137-149, 2007.

[39] Grover, C. "The National Childcare Strategy: The social regulation of lone mothers as a gendered reserve army of labour," Capital \& Class, vol. 29, no. 1, pp. 63-90, 2005. 


\section{BIOGRAPHIES OF AUTHORS}

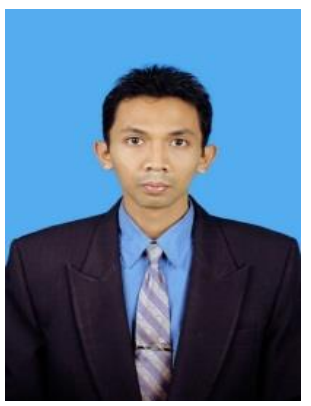

Fatwa Tentama was born on October 1, 1984 in Yogyakarta. Working as a lecturer at the Faculty of Psychology at Ahmad Dahlan University, Yogyakarta. Scientific focus and research on industrial psychology, educational psychology and training.

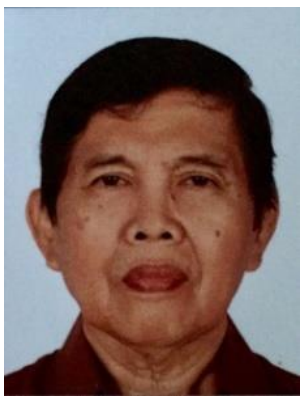

Subardjo was born on Desember 3, 1952 in Yogyakarta. Working as a lecturer at the Faculty of Law at Ahmad Dahlan University, Yogyakarta. Scientific focus and research on research methodology.

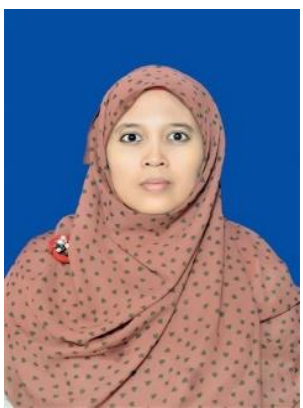

Surahma Asti Mulasari was born on October 22, 1982 in Yogyakarta. Working as a lecturer at the Faculty of Public Health, Ahmad Dahlan University, Yogyakarta. Scientific focus and research on public health science and training. 